\title{
THE BIOPSYCHOSOCIAL FACTORS AND GENITAL HYGIENE AFFECTING CERVICAL CANCER AT DR. MOEWARDI HOSPITAL, SURAKARTA, CENTRAL JAVA
}

\author{
Afriza Umami'), Setyo Sri Rahardjo²), Bhisma Murti1) \\ 1)Masters Program in Public Health, Universitas Sebelas Maret \\ ${ }^{2)}$ Faculty of Medicine, Universitas Sebelas Maret
}

\begin{abstract}
Background: Cervical cancer is a major public health issue. It is the second most common cancer in women worldwide. Worldwide, it was estimated that 493,000 new cases and 274,000 deaths occurring every year according to the statistics of the International Agency for Research on Cancer. The prevalence of cervical cancer in Indonesia was $0.8 \%$ with an estimated 98.692 cases. This study aimed to determine the biopsychosocial factors and genital hygiene affecting cervical cancer.

Subjects and Method: This was a case-control study conducted at Dr. Moewardi Hospital, Surakarta, from December 2017 to February 2018. A total of 178 study subjects including 95 women with cervical cancer (case) and 83 women without cervical cancer (control) were selected by fixed disease sampling. The dependent variable was cervical cancer. The independent variables were age at first sexual intercourse, number of sexual partners, body mass index (BMI), stress, education, income, and genital hygiene. Cervical cancer data was collected by medical record. The other data were collected by questionnaire. The data were analyzed by path analysis model.

Results: The risk of cervical cancer increased with the number of sexual partner $>1(b=1.91 ; 95 \% \mathrm{CI}=0.31$ to $3.49 ; \mathrm{p}=0.019), \mathrm{BMI} \geq 25(\mathrm{~b}=0.98 ; 95 \% \mathrm{CI}=-0.06$ to 2.04; $\mathrm{p}=0.067)$, and stress $(\mathrm{b}=1.59 ; 95 \% \mathrm{CI}=0.39$ to $2.80 ; \mathrm{p}=0.009)$. The risk of cervical cancer decreased with higher education $(b=-3.58 ; 95 \% \mathrm{CI}=-4.77$ to 2.39; $\mathrm{p}<0.001)$, higher income $(\mathrm{b}=-1.49 ; 95 \% \mathrm{CI}=-2.73$ to $-0.25 ; \mathrm{p}=0.019)$, age at first sexual intercourse $\geq 18$ years $(b=-1.36 ; 95 \% \mathrm{CI}=-2.52$ to $-0.21 ; \mathrm{p}=0.020)$, and genital hygiene $(\mathrm{b}=-1.24 ; 95 \% \mathrm{CI}=-2.35$ to $-0.13 ; \mathrm{p}=0.028)$. The risk of cervical cancer was indirectly affected by genital hygiene and the number of sexual partner.

Conclusion: The risk of cervical cancer increases with the number of sexual partner, BMI, and stress, but decreases with higher education, higher income, age at first sexual intercourse, and genital hygiene.
\end{abstract}

Keywords: cervical cancer, biopsychosocial factors, genital hygiene, path analysis

\section{Correspondence:}

Afriza Umami. Masters Program in Public Health, Universitas Sebelas Maret, Jl. Ir. Sutami 36 A, Surakarta, Central Java. Email: afrizaumami20@gmail.com.

Mobile: +6282254348041. 